\title{
UPAYA MENINGKATKAN HASIL BELAJAR ILMU PENGETAHUAN SOSIAL DENGAN MENERAPKAN METODE KOOPERATIF MODEL JIGSAW PADA SISWA KELAS V MI MIFTAHUL HUDA PUCANGAN MONTONG TUBAN TAHUN PELAJARAN 2017/2018
}

\author{
Oleh : \\ Nurlaili Dina Hafni, email : dinahafni@stitmatuban.ac.id \\ Muflihatun Nisa'
}

\begin{abstract}
Abstrak
This research is motivated by the fact that the still low learning outcomes of Social Sciences subjects in fifth grade MI Miftahul Huda Pucangan students. Possible learning methods that can affect student achievement are the cooperative jigsaw model. The problem of this research is to explain the efforts to improve learning outcomes of social science by applying the cooperative jigsaw method. The theories used in the conduct of this research include LAN about learning outcomes, social science and the cooperative jigsaw model method.

This research is expected to provide answers to the formulation of the problem (1) How is the application of the jigsaw cooperative method in the learning process of social science in class V MI Miftahul Huda Pucangan Montong Tuban in the academic year 2017/2018? and (2) Can the cooperative jigsaw method improve social studies learning outcomes for fifth grade MI Miftahul Huda Pucangan Montong Tuban students in the 2017/2018 academic year?

This type of research is classroom action research (CAR). The subjects of this study were 36 grade $V$ students, consisting of 18 boys and 18 girls. This research lasted for 2 cycles. For data collection techniques used observation techniques and data collection tools in the form of test questions. The collected data is then analyzed using a data processing method with descriptive statistical analysis which presents the data in the form of tables and bar charts. Then presented in each cycle to get information (observations), both from data collected from observation sheets and written tests.

The results of the study in the first cycle showed the average percentage of teacher activity in the first cycle meeting $178 \%$ and 2\% meetings 86\%, while in the second cycle 1 meeting 90\% and 95\% meetings 2. In addition to teacher activity, student activity in groups also increased, in cycle I meeting 1 the percentage of student activity was 68\% and meeting 2 was 77\%, whereas in cycle II at meeting 1 the percentage increased $80 \%$ and meeting $290 \%$. Social studies learning outcomes in pre-cycle with an average value of 68.94 and classical completeness of $42 \%$, the first cycle obtained an average value of 78.27 with classical completeness of $78 \%$. In the second cycle learning outcomes increased with an average value of 82.61 with $92 \%$ mastery learning. Means that at the end of the second cycle it has been shown that classical learning completeness is in accordance with indicators of success.

The results of these studies can be concluded, that by using the cooperative jigsaw model can increase teacher activity in managing learning and student activities in the learning process. Student learning outcomes in social studies lessons increase in accordance with predetermined minimal completeness criteria standards.
\end{abstract}

Kata Kunci : hasil belajar, ilmu pengetahuan sosial, dan metode kooperatif model jigsaw 


\section{LATAR BELAKANG}

Upaya peningkatan mutu pendidikan perlu dilakukan secara menyeluruh meliputi aspek pengetahuan, keterampilan, sikap dan nilai-nilai. Pengembangan aspek-aspek tersebut dilakukan untuk meningkatkan dan mengembangkan keterampilan hidup melalui seperangkat kompetensi agar siswa dapat bertahan hidup, menyesuaikan diri dan berhasil di waktu yang akan datang. Peningkatan mutu pendidikan di Sekolah Dasar (SD) atau Madrasah Ibtidaiyah (MI) harus bersifat menyeluruh, meliputi berbagai mata pelajaran yang diajarkan di Sekolah Dasar (SD) atau Madrasah Ibtidaiyah (MI).

Salah satu mata pelajaran di Madrasah Ibtidaiyah (MI) adalah Ilmu Pengetahuan Sosial. Mata pelajaran Ilmu Pengetahuan Sosial (IPS) sebagai ilmu pengetahuan, mulai diperkenalkan pada kurikulum tahun 1975 dan tahun 1986. Sampai kurikulum tahun 1994, IPS mulai diberikan pada siswa kelas 3. Namun sejak kurikulum 2004 atau KBK, IPS diperkenalkan sejak kelas 1. Mata pelajaran IPS berperan untuk memfungsionalkan dan merealisasikan ilmu-ilmu sosial yang bersifat teoritik ke dalam kehidupan nyata di masyarakat. Melalui pembelajaran IPS, siswa diharapkan mampu membawa dirinya secara dewasa dan bijak dalam kehidupan nyata. Selain itu, siswa juga diharapkan akan menjadi warga Negara yang mampu mengaplikasikan ilmunya dalam bentuk nyata, yang bermanfaat bagi kehidupan di masyarakat.

Dalam pembelajaran IPS, penggunaan model pembelajaran yang inovatif sangat diperlukan mengingat karakteristik IPS yang berupa konsep-konsep bertolak belakang dengan karakteristik siswa Sekolah Dasar (SD) atau Madrasah Ibtidaiyah (MI) yang masih berpikir konkret dan semi konkret, sehingga diperlukan suatu model pembelajaran yang mampu menjembatani antara karakteristik IPS dan karakteristik siswa. Sebagai guru di Sekolah Dasar (SD) atau Madrasah Ibtidaiyah (MI), guru harus betul-betul mampu memahami karakteristik siswa pada kelompok usia yang diajarnya. Karakteristik siswa Sekolah Dasar (SD) atau Madrasah Ibtidaiyah (MI) pada umumnya lebih memahami materi ajar yang berhubungan dengan dunia nyata atau pengalaman mereka.

Agar tujuan mata pelajaran IPS tersebut dapat tercapai dengan maksimal, seorang guru idealnya merencanakan dan melaksanakan proses pembelajaran yang maksimal pula. Pada kenyataannya, guru merencanakan dan melaksanakan pembelajaran secara konvensional, tanpa memperhatikan kebutuhan dan karakteristik siswa yang beragam. 
Secara umum, kendala yang ditemui adalah masih banyak guru yang melaksanakan pembelajaran secara konvensional. Siswa hanya diberi penjelasan dan catatan. Pembelajaran bersifat monoton, sehingga banyak siswa yang kurang termotivasi untuk mengikuti pembelajaran. Hal ini dapat dilihat dari keaktifan kelas yang masih dinilai kurang, hanya beberapa orang yang terlihat menjawab pertanyaan guru dan mengajukan pertanyaan. Kurangnya perhatian siswa dalam menerima materi pelajaran yang disampaikan guru, siswa cenderung melakukan keaktifan lain yang dapat mengganggu proses pembelajaran, selain itu tidak adanya persiapan dari siswa ketika akan memulai pelajaran. Oleh karena itu semua menjadikan hasil atau prestasi belajar dalam mata pelajaran IPS yang diperoleh siswa rendah. Rendahnya hasil belajar siswa masih banyak yang dibawah KKM yaitu rata-rata 68,94 sedangkan KKMnya adalah 70 .

Untuk memperbaiki dan memecahkan persoalan dalam proses pembelajaran dan hasil pembelajaran perlu perencanaan yang menerapkan model pembelajaran yang menuntut keterlibatan siswa secara aktif. Salah satu model pembelajaran yang melibatkan siswa secara aktif adalah dengan menggunakan metode kooperatif model jigsaw.

\section{KAJIAN PUSTAKA}

\section{1) Hasil Belajar}

Hasil belajar menurut Gagne \& Briggs" adalah "kemampuan-kemampuan yang dimiliki siswa sebagai akibat perbuatan belajar dan dapat diamati melalui penampilan siswa (learner's performance)". Sedangkan menurut Hamalik " "Hasil belajar adalah bila seseorang telah belajar akan terjadi perubahan tingkah laku pada orang tersebut misalnya dari tidak tahu menjadi tahu, dari tidak mengerti menjadi mengerti". "Hasil belajar adalah kemampuan yang dimiliki oleh siswa setelah menerima pengalaman belajar"3. Hasil belajar merupakan perubahan tingkah laku yang baru setelah melalui proses belajar. Perolehan aspek-aspek perubahan perilaku tersebut tergantung pada apa yang dipelajari oleh pembelajar.

\footnotetext{
${ }_{1}^{1}$ Jamil Suprihatiningrum, Strategi Pembelajaran Teori dan Aplikasi, Ar-Ruzz, Jogjakarta, 2013, hlm. 37

${ }^{2}$ Oemar Hamalik, Proses Belajar Mengajar, Exsamedia, Jakarta, 2008, hlm 30

${ }^{3}$ Nana Sudjana, 2006. Penilaian Hasil Belajar dan Proses Belajar Mengajar, PT. Remaja Rosdakarya, Bandung, 2006, hlm 22
} 
Menurut Darsono "hasil belajar siswa merupakan suatu puncak proses pembelajaran"4. Hasil belajar tersebut terjadi terutama berkat evaluasi guru. Sudjana ${ }^{5}$ menyatakan bahwa "proses penilaian terhadap hasil belajar dapat memberikan informasi kepada guru tentang kemajuan siswa dalam upaya mencapai tujuan-tujuan belajarnya melalui kegiatan belajar". Oleh karena itu penilaian hasil belajar mempunyai peranan yang penting dalam proses belajar.

Dalam sistem pendidikan nasional, hasil belajar dibagi menjadi tiga domain yaitu domain (ranah kognitif), domain (ranah afektif), domain (ranah psikomotor). Hal tersebut sesuai dengan pendapat Bloom yang dikutip oleh Sumiati mengemukakan bahwa "hasil belajar terdiri dari (1) Domain Kognitif, (2) Domain Afektif dan (3) Domain Psikomotorik"6.

\section{2) Ilmu Pengetahuan Sosial (IPS) di Sekolah Dasar}

Pada hakikatnya, Ilmu Pengetahuan Sosial (IPS) menjadi suatu mata pelajaran yang dapat mengantarkan peserta didik untuk dapat menjawab masalah-masalah mendasar tentang individu, masyarakat, pranata sosial, problem sosial, perubahan sosial, dan kehidupan masyarakat berbangsa, dari waktu ke waktu. Mata pelajaran IPS berperan untuk memfungsionalkan dan merealisasikan ilmu- ilmu sosial yang bersifat teoritik ke dalam kehidupan nyata di masyarakat. Melalui pembelajaran IPS, siswa diharapkan mampu membawa dirinya secara dewasa dan bijak dalam kehidupan nyata. Selain itu, siswa juga diharapkan akan menjadi warga Negara yang mampu mengaplikasikan ilmunya dalam bentuk nyata, yang bermanfaat bagi kehidupan di masyarakat.

Mata pelajaran IPS disekolah dasar marupakan program pengajaran yang bertujuan untuk mengembangkan potensi peserta didik agar peka terhadap masalah sosial yang terjadi dimasyarakat, memilki sikap mental positif terhadap perbaikan segala ketimpangan yang terjadi, dan terampil mengatasi setiap masalah yang terjadi sehari-hari baik yang menimpa dirinya sendiri maupun yang menimpa masyarakat.

\section{Menurut Abdul Aziz Wahab ${ }^{7}$}

\footnotetext{
${ }^{4}$ Darsono, Belajar dan Pembelajaran, IKIP Press, 2000, hlm 30

${ }^{5}$ Nana Sudjana, 2006. Penilaian Hasil Belajar dan Proses Belajar Mengajar, PT. Remaja Rosdakarya, Bandung, 2006, hlm 22

${ }^{6}$ Sumiati, Metode Pembelajaran, Wacana Prima, Bandung, 2009, hlm 34

${ }^{7}$ Abdul aziz Wahab, Metode dan Model-Model Mengajar IPS, Alfabeta, Bandung, 2009, hlm 17
} 
Bertujuan untuk (1) Mempersiapkan siswa untuk studi lanjut di bidang social sciences, (2)Mendidik kewarganegaraan yang baik, (3) Mempelajari akan masalah-masalah sosial yang pantang bicarakan di muka umum, (4) Pembinaan warga negara Indonesia atas dasar moral Pancasila/UUD 1945 secara standard dan intensif untuk ditanamkan kepada siswa sehingga terpupuk kemauan dan tekad untuk hidup bertanggung jawab demi keselamatan diri, bangsa, negara, dan tanah air, dan (5) Sikap sosial yang rasional dalam kehidupan.

\section{3) Metode Kooperatif Model Jigsaw}

Model pembelajaran yang saat ini yang banyak digunakan untuk mewujudkan kegiatan belajar mengajar yang berpusat pada siswa (student oriented) adalah Cooperative Learning, model ini bertujuan untuk mengatasi permasalahan yang ditemukan guru dalam mengaktifkan siswa, yang tidak dapat bekerja sama dengan orang lain, siswa yang agresif dan tidak peduli pada yang lain. Yamin, $\mathrm{dkk}^{8}$ mengatakan bahwa:

Strategi Pembelajaran Kooperatif adalah strategi pembelajaran yang sifatnya menuntut kerja sama suatu tim atau kelompok. Kooperatif adalah mengerjakan suatu bersama-sama dengan saling membantu satu sama lain. Sedangkan pembelajaran kooperatif merupakan model pembelajaran yang mengutamakan kerja sama diantara siswa untuk mencapai tujuan pembelajaran.

Jigsaw pada hakikatnya melibatkan tugas yang memungkinkan siswa saling membantu dan mendukung satu sama lain dalam menyelesaikan tugas. Dalam model pembelajaran ini siswa akan memiliki persepsi yang sama, mempunyai tanggung jawab individual dan kelompok dalam mempelajari materi yang diberikan, saling membagi tugas dan tanggung jawab yang sama besarnya dalam kelompok serta dapat belajar kepemimpinan.

Didalam pelaksanaan pembelajaran kooperatif model jigsaw, kelas dibagi ke dalam beberapa kelompok yang terdiri dari kelompok asal dan kelompok ahli. Kelompok asal adalah kelompok induk siswa yang beranggotakan siswa dengan kemampuan asal yang berbeda. Kelompok ahli adalah kelompok siswa yang terdiri dari anggota kelompok asal yang berbeda yang ditugaskan untuk mempelajari dan mendalami topik tertentu dan menyelesaikan tugas-tugas yang berhubungan dengan topik untuk kemudian dijelaskan kepada kelompok asal. Arends dalam Suprihatiningrum ${ }^{9}$ menggambarkan hubungan antara kelompok ahli dengan kelompok asal sebagai berikut:

Kelompok Asal

\footnotetext{
${ }^{8}$ Yamin, dkk, Taktik Mengembangkan Kemampuan Inidividu Siswa, GP Press, 2008, hlm 74

${ }^{9}$ Jamil Suprihatiningrum, Strategi Pembelajaran Teori dan Aplikasi, Ar-Ruzz, Jogjakarta, 2013, hlm. 205
} 


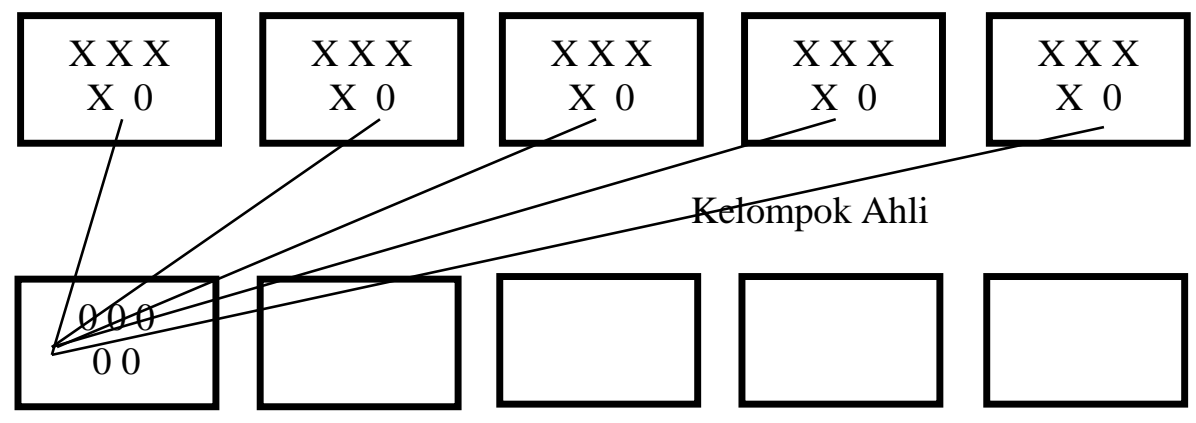

Gambar Ilustrasi Kegiatan Pembelajaran Kooperatif Model Jigsaw

Berdasarkan bagan tersebut dapat dijelaskan bahwa anggota dari kelompok asal yang berbeda bertemu dengan topik yang sama dalam kelompok ahli untuk berdiskusi dan membahas materi yang ditugaskan pada masing-masing anggota kelompok serta membantu satu sama lain untuk mempelajari topik tersebut. Setelah pembahasan selesai, para anggota kelompok kemudian kembali pada kelompok sal dan mengajarkan pada teman sekelompoknya apa yang telah mereka dapatkan pada saat di kelompok ahli.

Untuk lebih jelasnya, desain jigsaw dapat digambarkan sebagai berikut:

1.

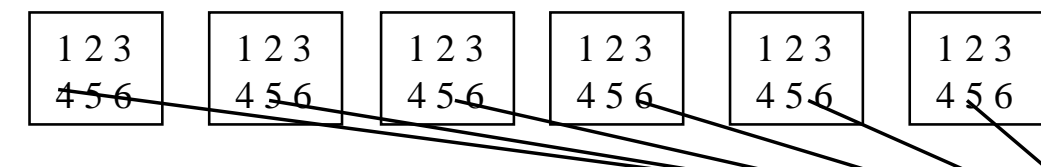

2.

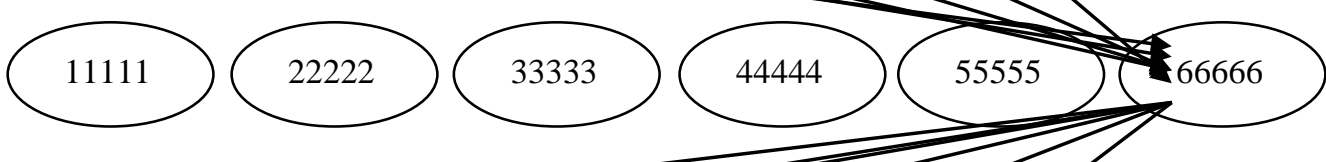

3.

\begin{tabular}{|c|c|c|c|c|c|}
\hline 12 & 123 & 123 & 123 & & 2 \\
\hline 456 & 456 & 456 & 456 & 456 & 456 \\
\hline
\end{tabular}

Pada gambar pertama menunjukkan bahwa ada sejumlah kelompok asal (misalnya 6) dan setiap kelompok masing-masing membawa hal yang harus diselesaikan, kemudian masing-masing mengelompokkan diri sesuai dengan masalahnya (ke dalam kelompok ahli), seperti pada gambar kedua. Masalah tersebut didiskusikan dalam kelompok, setelah mereka menemukan jawaban kemudian mereka bergabung seperti pada kelompok pertama (kembali ke kelompok asal), seperti gambar di atas. Kemudian dalam kelompok asal, masing- masing anggota kelompok mengemukakan masalah dan hasil penyelesaiannya, atau materi yang 
telah dipelajari di kelompok ahli. Dengan demikian setiap orang memperoleh informasi yang sama dari berbagai masalah yang dipecahkan.

Pelaksanaan pembelajaran kooperatif model jigsaw dilakukan melalui langkahlangkah sebagai berikut :

1) Membentuk kelompok jigsaw yang terdiri atas 5 atau 6 siswa. Anggota kelompok hendaknya berbeda secara kelamin, budaya, ras, dan kemampuan;

2) Menunjuk salah satu siswa sebagai ketua kelompok. Ketua kelompok hendaknya dipilih yang paling dewasa diantara yang lain;

3) Membagi materi menjadi 5 atau 6 bagian;

4) Meminta siswa untuk mempelajari satu bagian. Yakinkan bahwa siswa hanya mendapat satu bagian dan mempelajari bagian mereka sendiri;

5) Memberi waktu pada siswa untuk membaca bagiannya agar mereka tahu apa yang harus mereka lakukan. Dalam langkah ini siswa tidak perlu menghafal materinya;

6) Membentuk kelompok sesaat (kelompok ini disebut kelompok ahli. Siswa yang memiliki bagian yang sama membentuk satu kelompok dan mendiskusikan agar mereka benarbenar paham);

7) Mengembalikan siswa dalam kelompok asalnya (kelompok jigsaw) masing-masing;

8) Memberi waktu kepada setiap siswa untuk menjelaskan apa yang mereka peroleh dalam kelompok ahli dan siswa diberi kesempatan untuk bertanya dan meminta penjelasan;

9) Guru dapat berkeliling dari kelompok satu ke kelompok untuk mengawasi prosesnya. Guru dapat memberikan bantuan penjelasan atau mengintervensi secara tidak langsung;

10) Pada akhir pelajaran siswa diminta untuk mengerjakan tes atau kuis agar mereka sadar bahwa pelajaran berlangsung serius, bukan hanya bermain.

Pemaparan diatas menunjukkan bahwa model jigsaw didesain untuk meningkatkan rasa tanggung jawab, yaitu bertanggung jawab terhadap anggota kelompok dan bertanggung jawab terhadap diri sendiri. Siswa juga dituntut saling ketergantungan positif terhadap kelompoknya. Dalam hal ini kunci model jigsaw adalah interdependensi setiap siswa terhadap anggota tim yang lain. Jadi guru merupakan fasilitator kagiatan belajar, bukan sebagai pusat atau sumber segala informasi, dengan demikian siswa akan memiliki kesempatan untuk berkembang dalam berbagai kemampuan dan juga akan meningkatkan kreativitas siswa. 


\section{METODOLOGI PENELITIAN}

\section{1) Rancangan Penelitian}

Penelitian ini termasuk penelitian tindakan kelas (classroom action research). Menurut Sanjaya" "PTK merupakan salah satu upaya yang dapat dilakukan guru untuk meningkatkan kualitas peran dan tanggung jawab guru khususnya dalam pengelolaan pembelajaran". Tujuan utama dari penelitian tindakan kelas yaitu untuk memperbaiki dan meningkatkan kualitas pembelajaran. Perbaikan tersebut dilaksanakan secara bertahap dan terus menerus selama penelitian dilakukan. Dalam penelitian ini peneliti menggunakan Model Kemmis dan Mc.Taggart yang dikenal dengan model spiral.

Rencana tindakan yang akan dilakukan peneliti dalam penelitian ini melalui 4 tahap berupa perencanaan, tindakan, observasi, dan refleksi.

\section{2) Lokasi dan Waktu Penelitian}

Penelitian ini dilaksanakan di MI Miftahul Huda Pucangan pada mata pelajaran Ilmu Pengetahuan Sosial.. Alasan peneliti memilih MI Miftahul Huda dikarenakan masih banyak guru yang menggunakan metode ceramah sehingga peserta didik kurang termotivasi dalam proses belajar. Penelitian ini dilaksanakan mulai tanggal 16 Januari - 6 Februari 2018. Dalam penelitian ini dilaksanakan selama 2 Siklus, setiap siklusnya terdiri dari 2 kali pertemuan.

\section{3) Subjek Penelitian}

Subjek penelitian ini adalah siswa kelas V MI Miftahul Huda Pucangan tahun pelajaran 2017/2018 semester genap yang berjumlah 36 siswa terdiri dari 18 siswa perempuan dan18 siswa laki-laki. Alasan peneliti memilih kelas $\mathrm{V}$ sebagai subjek penelitian karena berdasarkan observasi peneliti menemukan permasalahan bahwa pada siswa kelas $\mathrm{V}$ hasil belajar IPS masih rendah. Hal ini dikarenakan pembelajaran belum menggunakan metode pembelajaran yang tepat.

\section{4) Instrumen Penelitian}

\footnotetext{
${ }^{10}$ Wina Sanjaya, Strategi Penbelajaran Berorientasi Standar Proses Pendidikan, Kencana Prenada Media Grup, Jakarta, 2009, hlm. 13
} 
Penelitian ini menggunakan beberapa instrumen untuk mengumpulkan data-data yang valid. Instrumen yang digunakan dalam penelitian ini adalah Lembar Observasi, Soal Tes Hasil Belajar dan Dokumentasi

\section{5) Prosedur Pengumpulan Data}

Prosedur pengumpulan data merupakan langkah yang paling utama dalam penelitian, karena tujuan utama dari penelitian adalah mendapatkan data, maka peneliti tidak akan mendapatkan data yang memenuhi data yang ditetapkan. Adapun penjelasan tentang metode pengumpulan data dalam Penelitian Tindakan Kelas adalah dengan menggunakan observasi, tes dan dokumentasi

\section{6) Analisis Data}

Teknik analisis data ini adalah menggunakan analisis data kualitatif dan analisis data kuantitatif, yaitu dimulai dari menghimpun data, menyusun atau mengatur data, mengolah data, menyajikan data dan menganalisis data angka guna memberikan gambaran tentang suatu gejala, peristiwa atau keadaan.

\section{HASIL PENELITIAN DAN PEMBAHASAN}

\section{1) Hasil Penelitian}

Hasil penelitian ini diperoleh dari proses pembelajara yang berlangsung selama dua siklus yang menggunakan metode kooperatif model jigsaw.

\section{a. Hasil Pra Siklus}

Data awal yang peneliti anggap sebagai pedoman awal melakukan penelitian yaitu menggunakan hasil tes siswa yang dilakukan oleh guru sebelum adanya tindakan. Data tersebut nantinya digunakan sebagai patokan awal sebelum dilakukan tindakan. Penelitian ini dimulai dengan observasi dan wawancara dengan guru mata pelajaran kelas $\mathrm{V}$. Berdasarkan wawancara dan observasi, permasalahan yang terjadi di dalam kelas tersebut diantaranya adalah guru belum menggunakan metode yang bervariasi. Hal tersebut menyebabkan siswa kurang antusias dalam proses pembelajaran dan cenderung siswa pasif dalam proses pembelajaran. Adapun data awal sebelum tindakan adalah sebagai berikut:

\section{Tabel}

\section{Data Awal Pra Siklus}


Premiere Volume 1 No $1 \quad 2019$

\begin{tabular}{|c|c|c|c|c|c|c|}
\hline \multicolumn{2}{|c|}{ Jumlah Siswa } & \multicolumn{2}{c|}{ Persentase } & \multirow{2}{*}{$\begin{array}{c}\text { Rata-Rata } \\
\text { (Mean) }\end{array}$} & Median & Modus \\
\cline { 1 - 4 } Tuntas & Tidak Tuntas & Tuntas & Belum Tuntas & & 65 & 65 \\
\hline 15 & 21 & $42 \%$ & $58 \%$ & 68,94 & 65 \\
\hline
\end{tabular}

Berdasarkan tabel diatas dapat dijabarkan sebagai berikut, dari 36 siswa, sebanyak 18 siswa atau $42 \%$ sudah tuntas atau mencapai KKM. Sebanyak 21 siswa atau 58\% tidak tuntas atau tidak mencapai KKM. Rata-rata kelas sebesar 68,94 median 69,5 dan modus 67. Untuk memperjelas pemaparan tabel tersebut, dapat dilihat dalam diagram batang sebagai berikut ini:

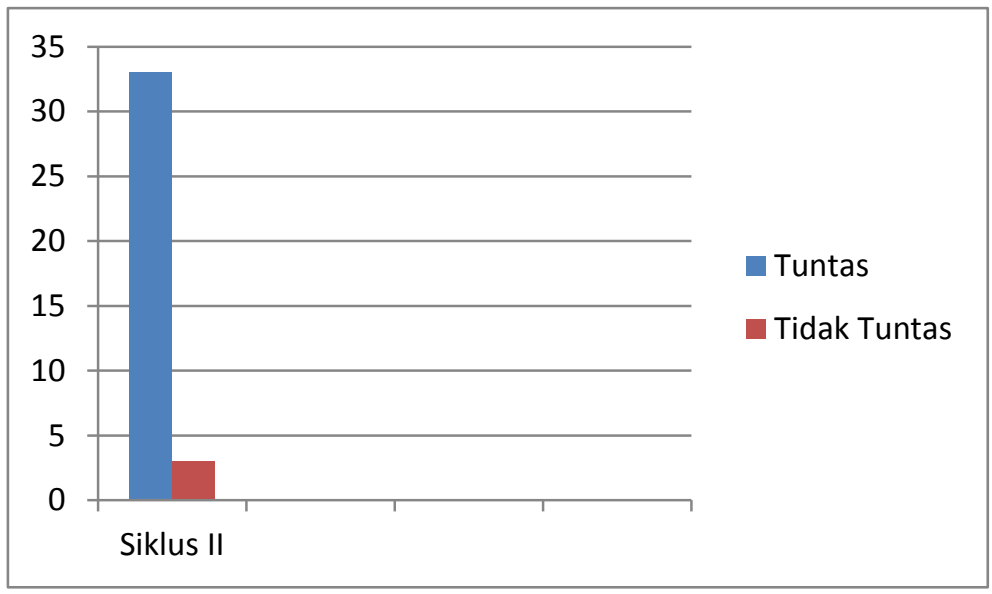

\section{b. Siklus I}

\section{1) Perencanaan}

1. Peneliti dan guru sebagai kolaborator menyiapkan materi yang akan disampaikan kepada siswa.

2. Menyiapkan rencana pelaksanaan pembelajaran (RPP).

3. Menyusun lembar observasi pembelajaran yang akan dilaksanakan. Lembar observasi ada 2 macam yaitu lembar observasi aktivitas siswa dan lembar observasi aktivitas guru. Lembar observasi ini digunakan untuk membandingkan aktivitas yang dilakukan siswa dan guru selama proses pembelajaran berlangsung dengan yang ada pada lembar observasi.

4. Menyusun dan menyiapkan LKS dan soal evaluasi untuk siswa. Soal akan diberikan pada setiap akhir siklus. Soal evaluasi disusun oleh peneliti dengan pertimbangan guru kelas. 


\section{2) Pelaksanaan}

\section{Kegiatan Awal}

a. Siswa berdoa bersama

b. Siswa dikondisikan untuk siap melakukan pembelajaran

c. Guru melakukan apersepsi yang berkaitan dengan materi penjajahan Jepang.

\section{Kegiatan Inti}

a. Guru membentuk 6 kelompok yang heterogen (akademik dan jenis kelamin), tiaptiap kelompok terdiri dari 6 siswa.

b. Guru memberikan materi tentang perjuangan melawan penjajahan Belanda kepada setiap anggota kelompok yang dibagi menjadi 6 sub bab.

c. Setiap anggota kelompok membaca sub bab yang ditugaskan dan bertanggung jawab untuk mempelajarinya. Anggota kelompok lain yang mempelajari sub bab yang sama bertemu dalam kelompok-kelompok ahli untuk mendiskusikannya.

d. Setiap anggota kelompok ahli setelah kembali ke kelompoknya bertugas untuk menjelaskan materi sub bab yang telah dipelajari kepada teman satu kelompoknya. Dan siswa juga bisa berinteraksi antara satu dengan yang lainnya.

e. Setelah diskusi kelompok selesai, masing-masing kelompok maju kedepan untuk mempresentasikan hasil diskusi kelompoknya. Sedangkan kelompok lain memperhatikan kemudian menanggapi dan mengajukan pertanyaan jika ada yang ingin ditanyakan.

f. Guru mengevaluasi hasil presentasi yang telah disampaikan oleh masing-masing kelompok.

g. Guru memberikan lembar evaluasi kepada setiap siswa untuk dikerjakan.

Diakhir pertemuan guru memberikan tes untuk mengetahui kemampuan siswa setelah melakukan pembelajaran.Hasil belajar siswa yang diperoleh dari pengerjaan soal evaluasi pada siklus I dapat dilihat pada tabel berikut ini 
Tabel

Data Hasil Belajar Siswa Siklus I

\begin{tabular}{|c|c|c|c|c|c|c|}
\hline \multicolumn{2}{|c|}{ Jumlah Siswa } & \multicolumn{2}{c|}{ Persentase } & Rata-Rata \\
Tuntas & Tidak Tuntas & Tuntas & Tidak Tuntas & Median & Modus \\
\hline 28 & 8 & $78 \%$ & $22 \%$ & 78,27 & 78 & 78 \\
\hline
\end{tabular}

Berdasarkan tabel diatas dapat dijabarkan sebagai berikut, dari 36 siswa, sebanyak 28 siswa atau 77\% sudah tuntas atau mencapai KKM. Sebanyak 8 siswa atau $36 \%$ tidak tuntas atau tidak mencapai KKM. Rata-rata kelas sebesar 78,27, median 78 dan modus juga 78. Untuk memperjelas pemaparan dari tabel tersebut, dapat dilihat dalam diagram batang sebagai berikut:

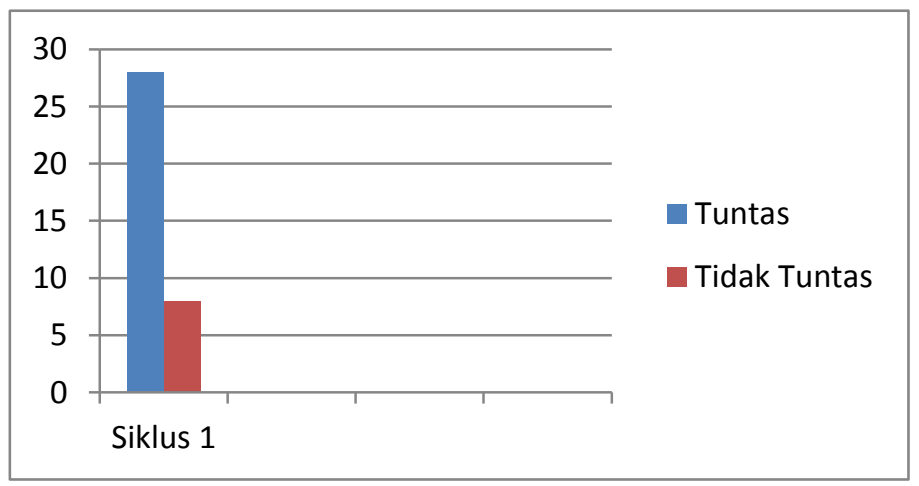

\section{Kegiatan Akhir}

Pada kegiatan akhir guru bersama siswa menyimpulkan hasil pembelajaran yang sudah dilaksanakan dan memberikan kesempatan siswa untuk mengajukan pertanyaan.

\section{1) Hasil Observasi}

Dalam hal ini observasi yang dilakukan peneliti ada dua yaitu sebagai berikut:

\section{a. Aktivitas Guru}

Data hasil observasi aktivitas guru digunakan untuk untuk mengetahui kempuan guru selama proses belajar mengajar. Hasil observasi pada masing-masing pertemuan tersebut dapat dilihat bahwa hasil observasi aktivitas guru pada siklus I menunjukkan adanya peningkatan aktivitas guru dalam mengajar sesuai indikator 
yang ada dalam lembar observasi. Skor yang diperoleh guru adalah 2138, rata-rata skor 85,52 dan persentase $86 \%$ dengan kategori "Baik".

\section{b. Aktivitas Siswa}

Pada hasil observasi di siklus 1 pada setiap aspeknya didapatkan hasil aspek A mencapai 79\%, aspek B mencapai 77\%, aspek C mencapai 76\%, aspek D mencapai 75\% dan aspek E mencapai 76\%. Dari hasil observasi tersebut maka dinyatakan bahwa pada pertemuan 2 lebih baik dibanding pertemuan 1. Penjelasan tentang data lengkap pertemuan 1 dan 2 dilampiran halaman. Jika disajikan dalam tabel maka hasil observasi tersebut adalah sebagai berikut:

\section{2) Refleksi Siklus I}

Refleksi tindakan pada siklus I ini lebih difokuskan pada masalah yang muncul selama tindakan. Berdasarkan deskripsi data siklus I, maka dalam pembelajaran ditemukan bahwa ketuntasan klasikal siswa hanya $78 \%$, maka penelitian akan dilanjutkan ke siklus berikutnya.

\section{c. Siklus II}

\section{1) Perencanaan}

1. Peneliti dan guru sebagai kolaborator menyiapkan materi yang akan disampaikan kepada siswa.

2. Menyiapkan rencana pelaksanaan pembelajaran (RPP).

3. Menyusun lembar observasi pembelajaran yang akan dilaksanakan. Lembar observasi ada 2 macam yaitu lembar observasi aktivitas siswa dan lembar observasi aktivitas guru. Lembar observasi ini digunakan untuk membandingkan aktivitas yang dilakukan siswa dan guru selama proses pembelajaran berlangsung dengan yang ada pada lembar observasi.

4. Menyusun dan menyiapkan LKS dan soal evaluasi untuk siswa. Soal akan diberikan pada setiap akhir siklus. Soal evaluasi disusun oleh peneliti dengan pertimbangan guru kelas.

\section{2) Pelaksanaan}

\section{Kegiatan Awal}

a. Siswa berdoa bersama

b. Siswa dikondisikan untuk siap melakukan pembelajaran 
c. Guru melakukan apersepsi yang berkaitan dengan materi penjajahan Jepang.

\section{Kegiatan Inti}

a. Guru membentuk 6 kelompok yang heterogen (akademik dan jenis kelamin), tiaptiap kelompok terdiri dari 6 siswa.

b. Guru memberikan materi tentang perjuangan melawan penjajahan Belanda kepada setiap anggota kelompok yang dibagi menjadi 6 sub bab.

c. Setiap anggota kelompok membaca sub bab yang ditugaskan dan bertanggung jawab untuk mempelajarinya. Anggota kelompok lain yang mempelajari sub bab yang sama bertemu dalam kelompok-kelompok ahli untuk mendiskusikannya.

d. Setiap anggota kelompok ahli setelah kembali ke kelompoknya bertugas untuk menjelaskan materi sub bab yang telah dipelajari kepada teman satu kelompoknya. Dan siswa juga bisa berinteraksi antara satu dengan yang lainnya.

e. Setelah diskusi kelompok selesai, masing-masing kelompok maju kedepan untuk mempreesentasikan hasil diskusi kelompoknya. Sedangkan kelompok lain memperhatikan kemudian menanggapi dan mengajukan pertanyaan jika ada yang ingin ditanyakan.

f. Guru mengevaluasi hasil presentasi yang telah disampaikan oleh masing-masing kelompok.

g. Guru memberikan lembar evaluasi kepada setiap siswa untuk dikerjakan.

Diakhir pertemuan guru melakukan tes guna mengetahui perkembangan kemampuan siswa. Hasil belajar yang diperoleh dari pengerjaan soal evaluasi pada siklus II dapat dilihat pada tabel berikut:

Tabel

Hasil Belajar Siswa Siklus II

\begin{tabular}{|c|c|c|c|c|c|c|}
\hline \multicolumn{2}{|c|}{ Jumlah Siswa } & \multicolumn{2}{c|}{ Persentase } & Rata-Rata \\
Tuntas & $\begin{array}{c}\text { Tidak } \\
\text { Tuntas }\end{array}$ & Tuntas & $\begin{array}{c}\text { Tidak } \\
\text { Tuntas }\end{array}$ & $\begin{array}{c}\text { Median } \\
\text { (Mean) }\end{array}$ & Modus \\
\hline 33 & 3 & $92 \%$ & $8 \%$ & 82,61 & 84,5 & 86 \\
\hline
\end{tabular}

Berdasarkan tabel diatas dapat dijabarkan sebagai berikut, dari 36 siswa, sebanyak 33 siswa atau 92\% sudah tuntas atau mencapai KKM. Sebanyak 3 siswa atau 
8\% tidak tuntas atau tidak mencapai KKM. Rata-rata kelas sebesar 82,61, median 84,5 dan modus 86. Untuk memperjelas pemaparan tabel tersebut, dapat dilihat dalam diagram batang sebagai berikut:

\section{Kegiatan Akhir}

Pada kegiatan akhir guru bersama siswa menyimpulkan hasil pembelajaran yang sudah dilaksanakan dan memberikan kesempatan siswa untuk mengajukan pertanyaan.

\section{1) Hasil Observasi}

Dalam hal ini observasi yang dilakukan peneliti ada dua yaitu sebagai berikut:

\section{Aktivitas Guru}

Berdasarkan observasi yang dilakukan dapat disimpulkan bahwa hasil observasi aktivitas guru pada siklus I menunjukkan adanya peningkatan aktivitas guru dalam mengajar sesuai indikator yang ada dalam lembar observasi. Jumlah skor yang diperoleh guru adalah 2376, rata-rata skor 95,04 dengan persentase $95 \%$ dengan kategori "sangat baik". Jadi pada siklus II aktivitas guru dapat dikatakan lebih baik dibandingkan pada siklus yang sebelumnya.

\section{Aktivitas Siswa}

Dari hasil pengamatan yang dilakukan, dapat diketahui bahwa pada setiap aspeknya mengalami peningkatan, aspek A mencapai 93\% dengan kategori “sangat aktif”, aspek B mencapai 89\% dengan kategori “aktif”, aspek C mencapai 90\% dengan kategori "sangat aktif", aspek D mencapai 89\% dengan kategori “aktif” dan aspek E mencapai 90\% dengan kategori “sangat aktif”. Dari hasil observasi tersebut maka dinyatakan bahwa pada siklus 2 lebih baik dibanding siklus 1.

\section{2) Refleksi Siklus II}

Refleksi dilaksanakan untuk menganalisis proses pembelajaran yang telah berlangsung pada siklus II, data tersebut meliputi data observasi proses pembelajaran dan tes hasil belajar. Refleksi ini dilaksanakan bersama teman sejawat yaitu kolaborator untuk bahan pertimbangan memperbaiki pembelajaran siklus berikut. Adapun hasil refleksi adalah sebagai berikut : 
a) Hasil tes menunjukkan bahwa nilai rata-rata siklus II adalah 82,61 dengan ketuntasan belajar 92\% yaitu sebanyak 33 siswa mengalami ketuntasan belajar dan sebesar $8 \%$ dari siswa yaitu hanya ada 3 siswa yang belum mengalami ketuntasan belajar.

b) Kerjasama siswa dalam kelompok sudah terjalin dengan baik, dan siswa merasa antusias dan senang dalam berdiskusi dengan kelompoknya, maupun dalam mengerjakan tugas.

c) Setiap anggota kelompok sudah merasa berani dan siap dalam mempresentasikan hasil diskusinya.

d) Siswa tidak takut atau ragu-ragu dalam bertanya, menyampaika pendapat maupun dalam mempresentasikan hasil diskusi.

e) Selama proses pembelajaran guru memberikan perhatian dan bimbingan kepada siswa maupun kelompok secara menyeluruh.

\section{2) Pembahasan}

\section{a. Penerapan Metode Kooperatif Model Jigsaw Pada Proses Belajar IPS}

\section{1) Aktivitas Guru dalam Pengelolaan Pembelajaran}

Berdasarkan hasil penelitian pada siklus I guru sudah memfokuskan pelaksanaan pembelajaran dengan metode kooperatif model jigsaw. Namun masih disibukkan pada pengarahan pembentukan kelompok dan pelaksanaan teknik jigsaw sehingga pembelajaran dan pelaksanaan diskusi kurang berjalan lancar. Pada siklus I, keaktifan guru dalam pembelajaran termasuk kategori cukup baik pada pertemuan 1 dengan persentase $78 \%$ dan pertemuan $286 \%$ dengan kategori baik. Pelaksanaan siklus II sudah terfokus pada penerapan metode kooperatif model jigsaw. Guru sudah menerapkan metode kooperatif model jigsaw dengan baik. Pada siklus II, keaktifan guru dalam pembelajaran termasuk dalam kategori sangat baik pada pertemuan 1 dengan persentase $90 \%$ dan pertemuan 2 mencapai 95\%. Berdasarkan hasil peningkatan aktivitas guru ini sesuai dengan kajian pustaka yang dikemukakan oleh Hamdani bahwa model pembelajaran kooperatif model jigsaw dapat meningkatkan aktivitas guru. 


\section{2) Aktivitas Siswa dalam Proses Pembelajaran}

Berdasarkan hasil pengamatan pelaksanaan observasi aktivitas siswa pada siklus I dalam penerapan metode kooperatif model jigsaw ini masih banyak siswa yang kurang aktif dalam berdiskusi, kurang konsentarsi sehingga siswa kurang bisa menjawab pertanyaan-pertanyaan dari guru dan kurang aktif dalam mempresentasikan hasil diskusi, hal ini dapat dilihat dari aktifitas siswa yang memperoleh persentase pada pertemuan $168 \%$ (cukup) dan pertemuan 2 mencapai 77\% (sedang) sehingga hal ini juga mempengaruhi hasil belajar siswa. Tetapi dari hasil observasi aktivitas siswa pada siklus II diperoleh persentase pada pertemuan 1 mencapai 80\% (aktif) dan pertemuan 2 mencapai 90\% (sangat aktif), siswa aktif dalam proses pembelajaran dan mampu mempresentasikan hasil diskusinya, sehingga dengan metode kooperatif model jigsaw ini siswa lebih aktif dan membuat siswa lebih bersemangat dalam proses pembelajaran. Berdasarkan hasil peningkatan akivitas siswa ini sesuai dengan kajian pustaka yang dikemukakan oleh Hamdani yang mengatakan bahwa metode kooperatif model jigsaw dapat meningkatkan keaktifan siswa.

\section{a. Peningkatan Hasil Belajar Siswa Pada Mata Pelajaran IPS dengan Menerapkan Metode Kooperatif Model Jigsaw}

Berdasarkan hasil penelitian yang telah dilaksanakan pada mata pelajaran IPS tentang perjuangan melawan penjajah melalui pembelajaran kooperatif model jigsaw pada siswa kelas V MI Miftahul Huda ketuntasan dari penilaian tes hasil belajar siswa pada siklus I menunjukkan nilai rata-rata kelas yaitu 78,27 dengan siswa yang tuntas yaitu sebanyak 28 siswa dari 36 jumlah siswa kelas $\mathrm{V}$ sehingga persentase yang diperoleh sebesar $78 \%$, karena siswa kurang aktif dalam pembelajaran sehingga nilai yang diperoleh siswa masih banyak yang belum mencapai KKM yaitu 270 . Pada perbaikan siklus II siswa mulai terbiasa menggunakan metode kooperatif model jigsaw sehingga hasil belajar siswa meningkat. Terlihat dari kenaikan nilai rata-rata kelas pada siklus II yaitu 82,61 dengan siswa yang tuntas sebanyak 33 siswa dari 36 jumlah siswa kelas V MI Miftahul Huda. Persentase ketuntasan hasil belajar siswa pada siklus II sebesar 92\%. Pembahasan diatas menunjukkan bahwa metode kooperatif model jigsaw dapat meningkatkan hasil belajar siswa yang sesuai dengan kajian pustaka yang dikemukakan 
oleh Wina Sanjaya. Dari hasil penelitian yang dilakukan dapat diketahui bahwa penelitian telah mengalami keberhasilan.

\section{PENUTUP}

\section{3) Kesimpulan}

Berdasarkan hasil penelitian tindakan kelas untuk meningkatkan minat siswa dalam pembelajaran IPS melaluui metode kooperatif model jigsaw pada siswa kelas V MI Miftahul Huda Pucangan. Peneliti dapat menarik kesimpulan sebagai berikut :

a. Penerapan metode kooperatif model jigsaw pada proses belajar IPS dapat meningkatkan aktivitas guru dan siswa secara bertahap. Aktivitas guru dalam menerapkan metode kooperatif model jigsaw pada mata pelajaran IPS pada siklus I persentasenya mencapai $86 \%$ dengan kategori baik. Sedangkan pada siklus II aktivitas guru dikategorikan sangat baik dengan rincian persentase pertemuan 2 mencapai 95\%. Kemudian aktivitas siswa dalam pembelajaran IPS menggunakan metode kooperatif model jigsaw pada siklus I pertemuan 2 mencapai $77 \%$ dengan kategori sedang. Sedangkan pada siklus II mencapai 90\% dengan kategori sangat aktif.

b. Hasil belajar IPS melalui penggunaan metode kooperatif model jigsaw dari pra siklus sampai dengan siklus II juga mengalami peningkatan secara bertahap. Perolehan nilai rata-rata pra siklus 68,94 dengan persentase ketuntasan belajar sebesar 42\%, dari 36 siswa yang tuntas hanya 15 siswa dan 21 siswa tidak tuntas. Pada siklus I rata-rata nilai 78,27 dengan persentase ketuntasan belajar 78\% yang tuntas 28 siswa dan 8 siswa tidak tuntas. Sedangkan pada siklus II rata-rata nilai 82,61 dengan persentase ketuntasan belajar 92\% dengan rincian siswa yang tuntas sebanyak 33 dan 3 siswa yang tidak tuntas. Berdasarkan hipotesis dalam penelitian ini membuktikan bahwa penerapan metode kooperatif model jigsaw dapat meningkatkan hasil belajar siswa sesuai dengan indikator keberhasilan.

\section{4) Saran}

Berdasarkan hasil penelitian yang disimpulkan diatas, maka saran yang dapat disimpulkan adalah : 


\section{Bagi Guru}

a) Metode pembelajaran kooperatif model jigsaw ini dapat digunakan sebagai alternatif pembelajaran IPS bagi siswa, karena dapat meningkatkan aktivitas siswa dalam prosees belajar, meningkatkan kerja sama dan interaksi sosial sehingga dapat digunakan sebagai bahan pertimbangan untuk kemajuan sekolah dan pengembangan ketrampilan guru dalam mengajar.

b) Hasil penelitian hendaknya dijadikan sebagai data awal bagi MI Miftahu Huda Pucangan Montong Tuban untuk meningkatkan kualitas pendidikan, terutama dalam menumbuhkan keaktifan belajar siswa dan sekaligus sebagai pedoman untuk melakukan pembinaan terhadap guru dalam upaya mengembangkan berbagai model pembelajaran di kelas agar tercipta keaktifan belajar siswa yang maksimal.

c) Penerapan metode kooperatif model jigsaw dapat meningkatkan keaktifan belajar siswa, maka kepada guru-guru yang ingin agar siswa yang diajarnya lebih aktif dan dapat meningkatkan hasil belajarnya, maka sebaiknya guru menggunakan model pembelajaran yang bervariasi seperti model pembelajaran kooperatif model jigsaw kepada siswa agar lebih meningkatkan diri untuk melaksanakan belajar kelompok terutama dalam mengerjakan tugas-tugas kelompok.

\section{Bagi Siswa}

a) Siswa perlu mengembangkan kerjasama dalam kelompok supaya bisa memahami pentingnya menghargai pendapat orang lain dalam pelaksanaan diskusi.

b) Siswa harus lebih berani dan percaya diri dalam mengajukan bertanya, menjawab pertanyaan dan mengemukakan pendapatnya sesuai dengan materi pembelajaran.

c) Hendaknya siswa dapat menjadikan hasil dari keaktifan ini sebagai langkah dalam meningkatkan prestasi belajar tentang hal-hal yang dipelajari dalam proses pembelajaran.

d) Siswa harus bisa lebih memahami pentinya belajar kelompok, karena dengan belajar kelompok siswa lebih mudah memecahkan suatu masalah dalam pembelajaran, sehingga tujuan pembelajaran dapat tercapai secara 


\section{REFERENSI}

Agustian , M. Haris. 2017. Pembelajaran IPS di Sekolah Dasar, (Online), https://agustianharis.wordpress.com/2010/11/29/pembelajaran-ips-di-sekolah-dasar/, diakses 15 Desember 2017.

Aries, Erna Febru dan Ari Dwi haryono. Penelitian Tindakan Kelas. Yogyakarta: Aditya Media Publishing.

Arikunto, Suharsimi. 2006. Prosedur Penelitian Suatu Pendekatan Praktik. Jakarta: Rineka Cipta.

Aziz. 2017. Pembelajaran IPS di Sekolah Dasar, (Online), http://azissandobatu.blogspot.co.id/2015/09/pembelajaran-ips-di-sekolah.html, diakses 21 Desember 2017.

Darsono. Darsono. Belajar dan pembelajaran. Semarang : IKIP Press

Gunawan, Rudy. 2011. Pendidikan IPS. Bandung: Alfabeta.

Hamalik, Oemar. 2008. Proses Belajar Mengajar. Jakarta : Exsamedia

Hamdani. 2011. Strategi Belajar Mengajar. Bandung: CV. PUSTAKA SETIA.

Hibatullah, Nur. 2018. Pengertian Belajar Dan Hasil Belajar, (Online), http://nurhibatullah.blogspot.com/2015/12/pengertian-belajar-dan-hasil-belajar.html, diakses 17 Januari 2017.

Hidayati, dkk. 2008. Pengembangan IPS SD. Yogyakarta: Dirjen Pendidikan Tinggi Depdiknas.

Indiriana, St. Zulfaidah. 2018. Pengertian Dan Karakteristik Penelitian Tindakan Kelas (PTK), (Online), http://zulfaidah-indriana.blogspot.co.id/2013/05/pengertian-dankarakteristik-penelitian.html, diakses 14 Januari 2018.

Ischak SU, dkk. 2003. Pendidikan IPS di SD. Jakarta: Universitas Terbuka.

Ishjoni. 2007. 2007. Cooperatif Learning. Bandung: Alfabeta.

Muhsetyo, Gatot. 2007. Pembelajaran Matematika SD. Jakarta: Universitas Terbuka.

Sanjaya, Wina. 2009. Strategi Penbelajaran Berorientasi Standar Proses Pendidikan. Jakarta: Kencana Prenada Media Grup.

Siska, Yuliati. 2016. Konsep Dasar IPS untuk SD/MI. Yogyakarta: Penerbit Garudhawaca.

Soemantri. 2001. Menggagas Pembahasan Pendidikan IPS. Bandung: PT. Remaja Rosdakarya.

Sudjana, Nana. 2014. Dasar-Dasar Proses Belajar Mengajar. Bandung: PT. Remaja Rosdakarya. 
Sudjana, Nana. 2006. Penilaian Hasil Belajar dan Proses Belajar Mengajar.Bandung: PT. Remaja Rosdakarya.

Sudjiono, Anas. 2008. Pengantar Statistik Pendidikan. Jakarta: Raja Grafindo Persada.

Sugiyono. 2012. Metode Penelitian Pendidikan. Bandung: ALFABETA.

Sumiati. 2009. Metode Pembelajaran. Bandung : Wacana Prima

Suprihatiningrum, Jamil. 2013. Strategi Pembelajaran Teori dan Aplikasi. Jogjakarta: Ar-Ruzz.

Susilo. 2018. Penerapan Metode Jigsaw untuk Meningkatkan Prestasi Belajar IPA Siswa Kelas IV Sifat dan Perubahan Wujud Benda ,(Online), https://susilofy.wordpress.com/2010/10/05/ptk-jigsaw/, diakses 09 Januari 2018.

Trianto. 2007. Model-Model Pembelajaran Inovatif Berorientasi Kontrukstivstik. Jakarta: Prestasi Pustaka.

Wahab, 2009. Abdul Aziz. Metode dan Model-Model Mengajar IPS. Bandung : Alfabeta

Yamin, Martinis dan Bansu. 2008. Taktik Mengembangkan Kemampuan Inidividu Siswa. Jakarta: GP Press. 